\title{
INTERVENSI MILITER ARAB SAUDI TERHADAP KONFLIK YAMAN UNTUK MEMBENDUNG PENGARUH IRAN DI TIMUR TENGAH
}

\author{
Rizki Pratama Putra, Maryam Jamilah, Poppy Irawan \\ Program Studi Ilmu Hubungan Internasional, Fakultas Ilmu Sosial dan \\ Ilmu Politik Universitas Andalas \\ Email: rizkipratamaputra14@gmail.com, \\ maryamjamilahmj73@gmail.com,poppyirawan@gmail.com
}

\begin{abstract}
This research aims to analyze military intervention measures and motives for Saudi military intervention in utilizing Yemen's position to stem Iran's influence in the Middle East. This intervention action is contrary to Saudi Arabian habits which historically tend not to intervene directly. This research describes the Yemeni conflict and uses a postmodern conceptual deterrence and geopolitical framework to explain Saudi Arabia's military intervention and the motives behind the military intervention. The findings of this research are that Saudi Arabia's military intervention against the Yemeni conflict aims to maintain the status quo of Saudi Arabia in the Middle East and to pressure and force the Houthis to withdraw from Yemen. While the motive for military intervention in Saudi Arabia is to seize power in the Middle East through the control of the oil trade route, Saudi Arabia's national security interests, and Saudi Arabia's perception of the Iranian threat which is classified as distorted and diffuse perception.
\end{abstract}

Keywords: Saudi Arabia, intervention, Yemen, containment, influence, motives, Iran.

\begin{abstract}
ABSTRAK
Penelitian ini bertujuan untuk menganalisis tindakan intervensi militer dan motif intervensi militer Arab Saudi dalam memanfaatkan posisi Yaman untuk membendung pengaruh Iran di Timur Tengah. Tindakan intervensi ini bertolak belakang dengan kebiasaan Arab Saudi yang secara historis cenderung untuk tidak melakukan intervensi secara langsung. Penelitian ini mendeskripsikan konflik Yaman dan menggunakan kerangka konseptual deterrence dan geopolitik post-modern untuk menjelaskan tindakan intervensi militer Arab Saudi dan motif dibalik tindakan intervensi militer tersebut. Temuan dari penelitian ini adalah tindakan intervensi militer Arab Saudi terhadap konflik Yaman bertujuan untuk mempertahankan status quo Arab Saudi di Timur Tengah serta untuk menekan dan memaksa kelompok Houthi mundur dari Yaman. Sedangkan motif intervensi militer Arab Saudi adalah perebutan power di Timur Tengah melalui penguasaan jalur perdagangan minyak, kepentingan keamanan nasional Arab Saudi, dan persepsi Arab Saudi terhadap ancaman Iran yang tergolong distorted dan diffuse perception.
\end{abstract}

Kata Kunci: Arab Saudi, intervensi, Yaman, pembendungan, pengaruh, motif, Iran. 


\section{PENDAHULUAN}

Kondisi geopolitik di Timur Tengah cenderung identik dengan adanya konflik. Konflik dapat berupa permasalahan transnasional dalam berbagai macam aspek, baik itu dari segi keamanan, ekonomi, politik maupun ideologi. Salah satu konflik yang terus mewarnai kondisi geopolitik di timur tengah adalah konflik antara Arab Saudi - Iran. Arab Saudi dengan ideologi Islam sunni sedangkan Iran dengan Islam syiahnya merupakan kekuatan utama di kawasan timur tengah sejak jatuhnya Khilafah Turki Utsmani pada tahun 1924. (Zada, 2016).

Konflik antara Arab Saudi - Iran telah berlangsung dalam beberapa periode. Periode pertama berlangsung pada tahun 1924-1979 yang disebabkan oleh pencaplokan wilayah Khuzistan oleh Iran di bawah pimpinan Reza Shah yang dianggap mengkhawatirkan oleh pemimpin Arab Saudi, Raja Abdul Aziz. Periode kedua berlangsung pada tahun 1979 yang merupakan tahun dimana Revolusi Iran menjadi sebuah negara republik memicu persaingan terhadap doktrin keyakinan dan pandangan tentang Islam yang menantang sistem monarki yang telah lama dianut Arab Saudi. Konflik periode kedua ini kemudian berkembang menjadi perang dingin di wilayah Timur Tengah dan berlangsung hingga tahun 2003. Periode ketiga merupakan fenomena kontemporer yang berlangsung dari tahun 2003 sampai sekarang. Pada periode ini, konflik antara Arab Saudi - Iran diwarnai oleh aspek sektarianisme dimana kedua Negara selalu berada dalam posisi yang berbeda dalam menangani konflik yang muncul di kawasan, mulai dari Perang Irak, Konflik Lebanon, Konflik territorial Palestina - Israel, hingga Konflik Yaman.(Grumet, 2015)

Konflik yang terjadi di Yaman saat ini merupakan puncak dari gejolak yang telah terjadi selama bertahun-tahun. Diawali dari gelombang Arab Springs yang terjadi pada akhir tahun 2010, ikut menyeret Yaman ke dalam pusaran konflik. Dalam perkembangannya, konflik Yaman bertransformasi menjadi perang saudara yang semakin besar dan banyak memakan korban. Pada tanggal 21 September 2014, ibukota Yaman, Sanaa, jatuh ke tangan kelompok pemberontak Al Houthi (BBC.com, 2018). Setelah disandera sebagai tahanan rumah selama beberapa pekan oleh pemberontak Houthi, Presiden Abdu Rabbu Mansour Hadi melarikan diri ke kota Aden dan mengumumkan pemindahan ibukota Yaman dari Sanaa ke Aden.

Setelah merasa semakin terdesak oleh pemberontakan yang dilakukan 
Houthi, pada bulan Maret 2015 Presiden Abdu Rabbu Mansour Hadi memberikan pernyataan sekaligus meminta bantuan kepada negara-negara Arab untuk memproteksi Yaman dari upaya penggulingan pemerintahan resmi yang berdaulat, berikut pernyataan Presiden Hadi: "Yemen would have fallen in four days and would have been an Iranian state had it not been for the Operation Decisive Storm launched by the Arab military coalition under the leadership of Saudi Arabia"(Report, 2017).

Melalui Menteri Luar Negerinya, Pangeran Saud al Faisal, Arab Saudi mengatakan siap untuk mengambil tindakan militer yang diperlukan untuk mengatasi krisis politik di Yaman. Dengan dukungan penuh dari Amerika Serikat dan Inggris, Arab Saudi sebagai pemimpin koalisi militer bekerjasama dengan delapan negara Arab, yang terdiri dari Bahrain, Kuwait, Uni Emirat Arab, Mesir, Yordania, Maroko, dan Sudan.(The New York Times, 2015). Pada 25 Maret 2015, Arab Saudi melancarkan serangan militer besar-besaran ke Yaman untuk memberantas para pemberontak Houthi. Arab Saudi mengerahkan 100 pesawat tempur dan 150 ribu tentara untuk operasi militer ini (CNN, 2015)

Intervensi militer yang dilakukan Arab Saudi ke wilayah Yaman bertolak belakang dengan kebiasaan Arab Saudi yang secara historis hanya terlibat dalam proxy war.(The Guardian, 2009). Berdasarkan sejarahnya, Arab Saudi cenderung untuk menggunakan pihak ketiga dalam merespon konflik yang terjadi di wilayah Timur Tengah. Seperti pada tahun 1960an, Arab Saudi menggunakan tentara royalis mantan presiden Yaman, Ali Abdullah Saleh, dalam memerangi Pan Arabism presiden Mesir ketika itu, Gamal Abdel Nasser. Pada tahun 1980an, Arab Saudi menggunakan Irak yang ketika itu dipimpin oleh Saddam Hussein dalam menghadapi Iran. Pada tahun 1990an, Arab Saudi merespon upaya okupasi Irak terhadap wilayah Kuwait melalui sekutunya, Amerika Serikat.(The Guardian, 2009)

Pada tahun 2011, Arab Saudi melakukan intervensi militer ke wilayah Bahrain yang sedang bergejolak. Intervensi ini merupakan intervensi militer pertama yang dilakukan Arab Saudi ke luar negeri secara langsun (Khan, 2019). Selama beberapa dekade sebelumnya, Arab Saudi dikenal sebagai negara yang tidak agresif melakukan intervensi mengenai urusan dalam negeri negara lain dan juga tidak bertindak tegas mengenai isu-isu regional (Khan, 2019). Intervensi Arab Saudi ke Bahrain ditenggarai sebagai bentuk respon dari protes dan pemberontakan yang terjadi di Bahrain merupakan aksi dari warga Syi'ah yang disponsori oleh Iran (The Guardian, 2011) 
Ada beberapa penelitian terdahulu yang menganalisis permasalahan yang sama, yaitu penelitian yang dilakukan oleh Fozia Jan dan Shazia Majid yang berjudul “Yemen Crisis and the Role of Saudi Arabia”(Jan, Majid, 2017). Penelitian ini menjelaskan mengenai peran Arab Saudi dalam krisis yang terjadi di Yaman. Bekerja sama dengan Amerika Serikat, Arab Saudi memiliki pilihan untuk membagi Yaman sebagai alat untuk mengurangi pergeseran strategis dari kemenangan Houthi. Penelitian kedua adalah “Saudi Arabia - Iran's Foreign Policy Crisis: A Case Study of Execution of Saudi Shia Cleric Shaikh Nimr al-Nimr"(Mamadkhul, 2016) yang ditulis oleh Jirajoj Mamadkul. Artikel ini menjelaskan hubungan Arab Saudi - Iran yang telah mengalami konflik berkepanjangan sejak revolusi Iran 1979 semakin memburuk dengan dieksekusinya ulama Syi'ah Himh alim Nimr al-Nimr oleh Arab Saudi. Terdapat tiga faktor yang mempengaruhi hubungan Arab Saudi - Iran: 1) Ketidaksepahaman Sunni-Syi'ah, 2) Persaingan menjadi kekuatan regional di Timur Tengah, 3) Politik di OPEC. Studi menemukan bahwa akar penyebab dari krisis hubungan kedua negara adalah persaingan mereka untuk ambisi menjadi hegemonik di kawasan dan menjadi pemimpin di dunia muslim. Penelitian lainnya yang membahas hubungan antara Saudi dengan Iran adalah. artikel yang ditulis oleh Usjid U. Hameed yang berjudul "The Saudi-Iranian Rivalry: A Foreign Policy Analysis Approach" (Hameed, 2017). Dalam tulisannya, Usjid U. Hameed menggunakan pendekatan Foreign Policy Analysis (FPA) dalam melihat persaingan Arab Saudi Iran. Pendekatan ini berbasis agensi dimana kekhawatiran mengenai kekuatan dan ideologi relatif berfokus pada faktor pembuat kebijakan dalam negeri untuk menyatakan bahwa persaingan dimotivasi oleh isu-isu kekuasaan dan identitas serta politik dalam negeri.

Dari penelitian diatas dapat dilihat bahwa kajaian mengenai konflik Yaman dan konflik antara Saudi dan Iran belum dibahas dengan menggunakan pendekatan geopolitik postmodernism yang lebih holistik karena menggabungkan beberapa aspek yaitu: power, interest, influence dan perception. Berdasarkan penjelasan tersebut, penelitian ini bertujuan untuk menjabarkan motif tindakan Arab Saudi dalam membendung pengaruh Iran pada konflik Yaman dengan memakai perspektif geopolitik postmodern.

\section{METODE PENELITIAN}


Penelitian ini merupakan penelitian kualitatif, yaitu prosedur penelitian yang menghasilkan data deskriptif berupa kata-kata tertulis atau lisan dari orang-orang dan perilaku yang diamati (Bogdan, Biklen, 1992). Disamping itu peneliti menggunakan pendekatan kualitatif deskriptif analisis, diamana tujuan dari penelitian kualitatif deskriptif adalah untuk menghasilkan sebuah kesimpulan yang komprehensif mengenai kejadian spesifik yang dialami oleh individu maupun suatu kelompok. (Lambert, Lambert, 2012).

Data yang dibutuhkan dalam penelitian ini didapatkan dengan melakukan studi pustaka yang umumnya merupakan data sekunder. Data sekunder tersebut peneliti dapatkan melalui studi literatur (library research) yang terdapat dalam beberapa sumber seperti buku, jurnal ilmiah, artikel, makalah, website, majalah, media elektronik maupun dokumen-dokumen terkait dengan isu yang dibahas peneliti (Lambert, Lambert, 2012).

\section{HASIL DAN PEMBAHASAN}

\section{Posisi Strategis Yaman bagi Arab Saudi dan Iran}

Secara geografis, Yaman terletak di bagian Tenggara Timur Tengah, berbatasan langsung dengan Oman di bagian timur, di bagian selatan berbatasan dengan Laut Arab, di bagian barat berbatasan dengan Teluk Aden dan Laut Merah, serta Arab Saudi di bagian utara (Country Profile, 2008). Wilayah Yaman meliputi area seluas $527.970 \mathrm{~km}^{2}$, termasuk Kepulauan Perim di ujung selatan Laut Merah dan Kepulauan Socotra di pintu masuk Teluk Aden. Total wilayah daratan Yaman mencapai panjang $1.746 \mathrm{~km}$ dan berbagi perbatasan negara dengan Arab Saudi sepanjang 1.458 km (Country Profile, 2008).

Yaman tidak memiliki sungai permanen, namun panjang garis pantai Yaman mencapai 1.906 km mulai dari sepanjang Laut Arab, Teluk Aden, hingga Laut Merah. Di bidang maritim, Yaman mengklaim laut territorial sepanjang 12 mil laut, zona tambahan sepanjang 24 mil, zona ekonomi ekslusif sepanjang 200 mil, dan landas kontinen sepanjang 200 mil dari wilayah territorial (Country Profile, 2008).

Sementara itu, berdasarkan perkiraan PBB saat ini, populasi Yaman pada tahun 2017 mencapai 28,2 juta orang. Populasi penduduk Yaman mencapai 0,38\% dari total populasi dunia, yang menempatkan Yaman pada urutan ke-50 dalam daftar negara dengan tingkat ketergantungan menurut jumlah populasi dan menjadikan Yaman sebagai negara terpadat kedua di Jazirah Arab setelah Arab Saudi. Kepadatan penduduk di Yaman adalah $55 / \mathrm{km}^{2}$ (142 orang $/ \mathrm{mi}^{2}$ ). (Worldmeters, 2018) 
Setelah resmi melakukan unifikasi pada tahun 1990, Yaman secara resmi menjadi satu-satunya negara republik di Jazirah Arab. Menurut konstitusinya, sistem politik Republik Yaman didasarkan pada partisan dan politik pluralis. Konstitusi Yaman diratifikasi oleh referendum pada 16 Mei 1991. Konstitusi ini mendefinisikan Yaman sebagai negara Arab dan negara Islam yang independen, berdaulat, serta menetapkan syari'ah atau hukum islam sebagai dasar dari semua undang-undang (Country profile, 2008)

Di bidang hubungan luar negeri, Perang Teluk tahun 1990-1991 memberikan dampak negatif yang signifikan terhadap hubungan Yaman dengan negara-negara Barat dan negara-negara Arab (Country profile, 2008) Hal ini disebabkan oleh Yaman yang merupakan anggota Dewan Keamanan PBB pada masa itu memilih untuk abstain pada sejumlah resolusi Dewan Keamanan mengenai Irak dan Kuwait, menolak sanksi ekonomi terhadap Irak, menyerukan "solusi Arab" terhadap krisis tersebut. Negara-negara Teluk merespon tindakan Yaman dengan membatasi atau membatalkan program bantuan dan kontak diplomatik. Khususnya, Arab Saudi dan Kuwait yang memotong bantuan keuangan dan dukungan anggaran bagi pemerintah Yaman. Arab Saudi juga mengusir hampir 1 juta pekerja Yaman yang berada di Arab Saudi dan hal ini berdampak besar pada keuangan pemerintah Yaman (Country profile, 2008)

Sementara itu, Kuwait memutuskan hubungan diplomatik dengan Yaman hingga tahun 1999. Hubungan kedua negara kembali membaik pada tahun 2000 ketika Yaman menandatangani perjanjian perbatasan dengan Arab Saudi, Kuwait setuju untuk melanjutkan bantuan keuangan. Perjanjian tersebut ditandatangani oleh Yaman dan Arab Saudi setelah menyelesaikan sengketa selama 50 tahun antar kedua negara, yang kemudian ditandai dengan pembuatan titik koordinat, perbatasan daratan dan maritime Yaman (Country profile, 2008).

Yaman berkeinginan untuk bergabung dengan organisasi sub-regional Gulf Cooperation Council (GCC) yang terdiri dari Arab Saudi, Kuwait, Bahrain, Qatar, Uni Emirat Arab, dan Oman. GCC berfokus pada kerjasama ekonomi dan keamanan. Namun, Yaman sampai saat ini hanya menjadi negara observer dalam beberapa komite di GCC dikarenakan oraganisasi secara tradisional menentang aksesi negara tambahan. Ditambah lagi dengan adanya pengalaman historis dari Kuwait yang masih belum menerima Yaman terkait dukungannya kepada Irak selama Perang Teluk I (Sharp, 2011). Saat ini, kepentingan GCC terhadap Yaman adalah untuk mencegahnya menjadi negara gagal dan 
ketidakstabilannya menyebar ke negara-negara Teluk lainnya (Haykel, 2010). Sementara itu, Yaman diharuskan untuk mengekspor ribuan pekerjanya setiap tahun ke negara-negara Teluk untuk mengurangi beban ekonomi dalam negeri (Haykel, 2010).

Terkait dengan sikap pro terhadap Irak pada saat Perang Teluk I membuat hubungan Yaman dengan negara-negara Barat turut memanas. Hubungan tersebut kembali terbentuk pada pertengahan tahun 1990-an ketika negara-negara Barat mendesak lembaga keuangan International Monetary Fund (IMF) dan Bank Dunia untuk memperluas bantuan keuangan ke Yaman.(Country Profile, 2008)

Pada tahun 1999, Amerika Serikat mulai menggunakan pelabuhan di Kota Aden sebagai tempat transit pengisian bahan bakar bagi Angkatan Laut AS. Setelah tragedi pemboman kapal USS Cole pada bulan Oktober 2000 di pelabuhan Aden, Yaman memperketat pengawasan dan memperkuat upayanya melawan kelompok-kelompok islam yang bertanggung jawab atas serangan tersebut.(Country profile, 2008) Sejak 11 September 2001, hubungan antara Yaman dengan Amerika Serikat semakin membaik setelah AS memberikan bantuan keuangan dan dukungan militer, serta pengaruh AS dalam IMF yang memiliki keprihatinan serius tentang komitmen Yaman untuk melakukan reformasi ekonomi. Menurut Departemen Luar Negeri AS, Yaman dianggap sebagai mitra penting dalam memerangi terorisme global, pemberian bantuan militer, diplomatik, dan keuangan (Country profile, 2008).

Di bidang keamanan, Yaman memiliki kekuatan militer terbesar kedua di Jazirah Arab setelah Arab Saudi. Militer Yaman terdiri dari tentara, angkatan darat, angkatan laut, dan tentara cadangan. Pada tahun 2007, jumlah pasukan aktif diperkirakan mencapai 60.000 orang tentara, 1.700 orang angkatan laut, dan 5.000 orang angkatan udara (Country profile, 2008) Terlepas dari jumlah pasukan ini, peralatan militer Yaman dianggap ringan, ketinggalan zaman, tidak terawat dengan baik, terutama jika dibandingkan dengan peralatan senjata negara-negara Teluk lainnya.

Wilayah Yaman yang strategis menjadikannya sebagai jalur pelayaran internasional, terutama di daerah Teluk Aden dan selat Bab el Mandab. Kedua tempat ini dilalui oleh kapal-kapal tanker minyak maupun kapal kargo. Garis pantai yang panjang dan sangat luas serta tidak disertai dengan kemampuan Angkatan Lautnya yang tidak memadai memberikan ancaman bagi kemanan pelayaran dan perdangangan Yaman di jalur tersebut (Sharp, 2011). Bentuk nyata dari ancaman tersebut adalah perompak Somalia. Setiap tahun 
puluhan ribu warga Somalia menyeberangi Teluk Aden dan Laut Merah melalui kapal penyelundup untuk mencapai pantai Yaman.

Secara umum, Yaman cenderung tergolong sebagai miskin akan sumber daya alam. Berbanding terbalik dengan Arab Saudi yang kaya akan sumber daya mineral, cadangan energi yang dimiliki Yaman tergolong rendah. Departemen Energi Amerika Serikat menyatakan bahwa Yaman hanya memiliki sekitar 3 miliar barel cadangan minyak bumi. Meskipun pemerintah Yaman mengklaim bahwa negaranya memiliki 11,9 miliar barel minyak bumi dan 480 miliar gas alam (Makovsky, Misztal, 2011).

Wilayah Yaman yang diapit oleh Laut Merah, Teluk Aden dan Laut Arab membuat Yaman menguasai selat Bab el Mandeb. Bab el Mandeb adalah selat sempit selebar 18 mil laut yang merupakan salah satu jalur pelayaran perdangangan minyak tersibuk di dunia (Cordesman, 2015). Selat Bab el Mandeb dianggap sebagai chokepoint yang berada di ujung Afrika dan Timur Tengah dan menjadi penghubung antara Laut Mediterania dengan Samudera Hindia. Setiap harinya, selat ini dilewati oleh kapal-kapal tanker yang mengangkut minyak dari Teluk Persia menuju ke Asia, Eropa dan Amerika Utara yang diperkirakan mencapai 3,8 juta barel minyak per hari (Cordesman, 2015).

Ekspor minyak telah menjadi sumber pendapatan utama bagi pemerintah Yaman sejak produksi minyak dimulai pada tahun 1980-an. Akan tetapi, total produksi dan keseluruhan cadangan minyak Yaman terbukti jauh lebih sedikit dibandingkan dengan produksi minyak negara-negara Arab lainnya. Pada puncaknya tahun 2002, produksi harian minyak Yaman hanya kurang dari 5\% produksi Arab Saudi. Total produksi Yaman saat itu mencapai 457.000 barel per hari dan terus menurun hingga tahun 2009 menjadi 281.000 barel per hari. Menurut Badan Energi Internasional, produksi minyak harian Yaman diperkiran akan terus merosot menjadi 248.000 barel per hari pada tahun 2014 (Makovsky, 2011)

Berbanding terbalik dengan sektor minyak bumi, sektor gas alam Yaman memiliki harapan sedikit lebih baik karena jumlah cadangannya diperkirakan akan bertahan lebih lama dari cadangan minyak bumi. Pada bulan Oktober 2009, Liquefed Natural Gas Company Ltd. (YLNG) mulai menggarap proyek gas alam Yaman senilai 4,5 miliar dolar yang dipimpin oleh Total setelah beberapa kali mengalami penundaan (Fuchs, 2009). Proyek tersebut diproyeksikan menjadi program energi utama negara untuk masa yang akan datang. Proyek gas alam Yaman diperkirakan akan menghasilkan pendapatan pemerintah 
senilai 30-50 miliar dolar dalam 20-25 tahun ke depan atau setara dengan 15-20\% pendapatan tahunan pemerintah Sana'a. YLNG juga diperkirakan akan mampu mengeskpor 5,7 juta $\mathrm{m} 3 \mathrm{LNG}$ per tahun yang mana jumlah tersebut setara dengan produksi 180.000 barel minyak per hari selama setidaknya dua decade (Lidstone, 2011) Sebelum tahun 2014, Yaman sangat bergantung terhadap sumber daya alamnya yang sangat terbatas dan terus menurun. Minyak bumi dan gas alam menyumbang sekitar 25\% dari Product Domestic Bruto (PDB) dan 65 \% dari pendapatan pemerintah Yaman.

\section{Yaman bagi Iran}

Yaman merupakan negara terpadat kedua di Jazirah Arab setelah Arab Saudi dengan jumlah penduduk yang mencapai 28,2 juta orang dan sekitar $35 \%$ atau 9,8 juta orang dari jumlah populasinya merupakan kelompok Syi'ah (State.gov, 2015) Kelompok Syi'ah di Yaman berbasis di daerah bagian Utara Yaman, terutama di kota Sa'dah. Kelompok Syi'ah di Yaman didominasi oleh sekte Zaydi yang banyak melakukan pemberontakan terhadap rezim pemerintah karena disebabkan oleh faktor ketidakpuasan warga pada situasi politik dan ekonomi. (State.gov, 2015)

Dalam strategi politik luar negerinya saat ini Iran memiliki empat poin prioritas utama, yaitu: melestarikan rezim Republik Islam, menjaga kedaulatan Iran, membela ambisi pengembangan nuklirnya, dan memperluas pengaruhnya di kawasan dan dunia Islam (Dennis, 2010). Dukungan dalam bentuk politik dan militer yang diberikan Iran kepada kelompok Houthi di Yaman diyakini sebagai upaya perluasan pengaruh Iran di kawasan dan dunia Islam.

Dalam kebijakan luar negeri Iran, aspek keagamaan berperan sangat penting dalam menganalisis kebijakan Iran terhadap Arab Saudi, karena Arab Saudi merupakan rumah bagi kota-kota suci umat Islam. Iran mengkritik hubungan kedetakan antara Arab Saudi dengan Amerika Serikat dan mencoba melemahkan pengaruh Kerajaan Arab Saudi di kawasan (Alsis, Allison, Cordesman, 2011).

Secara lebih luas, Iran berusaha memperluas pengaruh politik, ekonomi, militernya di kawasan sambil mengatasi pengaruh aktor asing khususnya Amerika Serikat. (Alsis, Allison, Cordesman, 2011). Para pemimipin Iran menggunakan pengaruh populis mereka dan pendekatan "Arab Street" untuk mengurangi pengaruh rezim Arab Saudi dan mengangkat isu-isu seperti penganiayaan terhadap orang Palestina, dampak kehadiran Amerika Serikat di negara-negara Teluk, dan menggambarkan bahwa beberapa orang 
penguasa negara Teluk sebagai boneka Washington (Alsis, Allison, Cordesman, 2011).

Dalam upaya perluasan pengaruhnya, Iran menggunakan pengaruh ideologis dan politiknya untuk bersaing dengan negara-negara yang mayoritasnya menganut Islam Sunni, seperti di Bahrain, Iran memiliki pengaruh terhadap kelompok radikal Syia'ah Al-Haq; di Kuwait dan Arab Saudi, Iran menggunakan posisinyasebagai pemimpin Syi'ah untuk mendapatkan pengaruh diantara komunitas minoritas Syi'ah terutama dimasa ketegangan sektarian; sedangkan di Yaman, Iran dituduh menggunakan Syi'ah sebagai alasan untuk secara retoris mendukung pemberontakan kelompok Houthi dan bersaing dengan Arab Saudi dalam pengaruh politik. (Alsis, Allison, Cordesman, 2011).

\section{Yaman bagi Arab Saudi}

Terdapat dua poin penting mengenai pengaruh posisi strategis Yaman terhadap Arab Saudi. Pertama, keamanan politik dalam negeri Yaman akan berdampak terhadap kepentingan ekonomi Arab Saudi, dan Kedua, kondisi politik dalam negeri Yaman akan berdampak pada sektor keamanan Arab Saudi.

Arab Saudi memiliki 18\% cadangan minyak bumi dunia dan merupakan negara pengekspor minyak terbesar di dunia (opec.org, 2018). Sektor minyak dan gas menyumbang sekitar 50\% dari produk domestik bruto, dan sekitar $85 \%$ pendapatan ekspor Arab Saudi (opec.org, 2018).

Posisi Yaman yang strategis berdampak terhadap kepentingan ekonomi Arab Saudi yang bergantung terhadap ekspor minyak bumi. Secara ekonomi, posisi Yaman menjadi sangat penting karena keberadaan selat Bab el Mandeb yang berdekatan dengan selat Hormuz. Kedua Selat ini merupakan titik penting dalam akses perdagangan minyak dunia (Moussalli, 2018)

Selat Bab el Mandeb yang menghubungkan antara Laut Merah, Teluk Aden, dan Samudera Hindia berperan penting dalam perdagangan minyak Arab Saudi. Kelebihan selat tersebut berbanding lurus dengan Terusan Suez yang menghubungkan Laut Merah dengan Selat Hormuz di Teluk Persia. Sebagian besar perdagangan Arab Saudi dikirim melalui jalur laut. Pemberontakan yang dilakukan kelompok Houthi serta adanya indikasi bantuan yang dikirimkan oleh Iran membuat Arab Saudi khawatir bahwa jika kelompok Houthi berhasil mengambil kendali atas Yaman, mereka akan menutup akses Bab el Mandeb untuk Arab Saudi (Voice of Palestine, 2018) 
Arab Saudi telah memainkan peran yang dominan dalam membentuk politik dalam negeri Yaman dalam waktu yang lama. Bagi Arab Saudi, Yaman merupakan kepentingan keamanan yang sangat vital (Schmitz, 2017). Hal ini disebabkan oleh perbatasan kedua negara yang sangat panjang dan permasalahan demogafi Yaman. Populasi penduduk Yaman yang terus bertambah secara signifikan dikhawatirkan akan memberikan masalah bagi Arab Saudi apabila pemerintah Yaman tidak mampu mengelola perekonomiannya secara baik, sehingga penduduk Yaman yang sebagian besar tergolong miskin akan menyebar dan melintasi perbatasan kedua negara dan memberikan beban terhadap perekonomian Arab Saudi (Schmitz, 2017).

Selain itu, Arab Saudi juga khawatir atas ketidakmampuan Yaman untuk melindungi wilayahnya akan memberikan kesempatan berkembangnya kelompok teroris AQAP yang memiliki basis yang kuat di Yaman. Kelompok ini dikhawatirkan akan melancarkan serangan terhadap pejabat di Kerajaan dan menyebarkan pengaruhnya di wilayah Arab Saudi (Schmitz, 2017).

\section{Motif Intervensi Militer Arab Saudi terhadap Konflik Yaman}

\section{Motif Perebutan Power di Timur Tengah melalui Yaman}

Secara geografis kawasan Timur Tengah berbatasan dengan tujuh lautan yang strategis, yaitu Laut Tengah (Mediterania) yang berada pada perbatasan antara Mesir, Libya dan Tunisia; Laut Merah di perbatasan antara Arab Saudi dan Sudan; Laut Arab di bagian barat Samudera Hindia diantara Arab Saudi dan India; Laut Mati di perbatasan Yordania dan Israel; dan Laut Hitam di Turki dan Laut Aegean.

Selain itu Timur Tengah juga memiliki lima selat yang bernilai penting dalam perdagangan dunia, yaitu; (1) Selat Gibraltar yang digunakan sebagai jalan pintas perjalanan kapal-kapal dari Samudera Atlantik (Eropa dan Amerika) ke Asia. Selat Gibraltar terletak diantara Maroko dan Spanyol; (2) Selat Turki yang digunakan sebagai tempat transit perdagangan dari Samudera Atlantik ke Asia. Selat Turki juga menjadi jalan satu-satunya jalur perdagangan Rusia dari Laut Hitam ke Laut Tengah; (3) Terusan Suez yang merupakan jalur vital bagi pelayaran dari Laut Tengah ke Afrika dan Asia; (4) Selat Bab el Mandeb yang terletak di pesisir Yaman dan merupakan jalur perdagangan minyak yang digunakan kapal-kapal tanker menuju Terusan Suez - Laut Merah - Samudera Hindia - Selat Hormuz; (5) Selat Hormuz yang terletak di Iran sebelah utara dan Oman bagian selatan. Selat Hormuz sangat strategis karena menjadi jalur semua kapal dan transportasi 
minyak dari dan ke Teluk Persia - Laut Arab - Samudera Hindia (Priambod, 2017).

Menurut data dari U.S Energy Information Administrations (EIA), dapat disimpulkan bahwa selat Bab el Mandeb merupakan jalur pelayaran yang sangat vital bagi perdagangan minyak internasional. Pada tahun 2016, setiap harinya selat Bab el Mandeb dilewati sekitar 4,8 juta barel minyak per hari yang diangkut kapal-kapal tanker pengangkut minyak menuju Eropa, Amerika Serikat dan Asia. Selat tersebut menjadi pintu masuk bagi kapal-kapal tanker yang mengangkut minyak mentah maupun minyak olahan (petroleum) dari selat Hormuz menuju Laut Merah dan Terusan Suez. Laut Merah sendiri merupakan gerbang utama bagi perdagangan minyak negara-negara Arab menuju pasar ekspor yang perekonomiannya bergantung pada ekspor minyak terutama Arab Saudi.

Arab Saudi memiliki ambisi untuk menjadi pemimpin dalam dunia Arab dan Islam dengan koneksi geografis yang kuat ke Eropa, Asia, dan Afrika. (Saudi embassy, 2017). Koneksi geografis tersebut dibangun atas kerjasama perdagangan Arab Saudi dengan negara-negara mitra dagang seperti Cina, Jepang, Korea Selatan dan Uni Eropa terutama dalam sektor perdagangan minyak dan gas. Konflik yang terus terjadi di Yaman menjadi perhatian Arab Saudi karena jatuhnya pemerintahan Yaman ke dalam penguasaan kelompok Houthi yang dekat dengan Iran akan berdampak pada akses lalu lintas kapalkapal minyak. Apabila sewaktu-waktu kelompok Houthi menutup atau membatasi akses lalu lintas kapal untuk melewati Bab el Mandeb, tentunya akan berimbas kepada pasar energi internasional. Pasokan minyak akan tersendat dan menambah beban biaya dan waktu produksi yang lebih lama karena kapal-kapal tanker pengangkut minyak harus berputar menempuh rute yang lebih jauh melewati daerah selatan Afrika untuk menuju pasar Eropa dan Amerika Serikat.

Hal ini sejalan dengan pernyataan dari Menteri Luar Negeri Arab Saudi, Adel alJubeir yang mengatakan bahwa: "Do we want a Hezbollah (Houthi)-controlled country on our southern border? No. Not going to happen. Do we want a Hezbollah (Houthi)controlled country controlling access to the Red Sea where more than ten percent of the world trade takes place? No."(Isobel Coleman)

Penguasaan atau kontrol terhadap jalur strategis Bab el Mandeb menjadi motif utama bagi Arab Saudi dalam tindakan intervensi militer terhadap Yaman. Selat Bab el Mandeb yang berada di wilayah Yaman sangat berpengaruh terhadap stabilitas perdagangan Arab Saudi dikarenakan merupakan jalur utama dan setiap kapal yang 
berangkat ataupun datang dari Arab Saudi akan melewati selat tersebut.. Penguasaan dan kontrol terhadap jalur perdagangan menjadi hal mutlak yang harus dikuasai Arab Saudi untuk mencapai ambisinya. Tindakan intervensi militer Arab Saudi ke Yaman bertujuan untuk memastikan bahwa Bab el Mandeb tetap aman dan tersedia bagi semua pelayaran internasional setiap saat.

\section{Motif Kepentingan Keamanan Nasional Arab Saudi}

Konflik Yaman yang terjadi pada tahun 2015 memberikan dampak langsung terhadap stabilitas keamanan Arab Saudi yang berbatasan langsung dengan Yaman. Perbatasan darat antara Arab Saudi dan Yaman mencapai $1.460 \mathrm{~km}$. Panjangnya daerah perbatasan dengan Yaman memberikan masalah bagi Arab Saudi dalam beberapa hal, seperti; Pertama, lalu lintas ilegal yang dilakukan oleh berbagai kelompok, termasuk pekerja dari Yaman yang menyeberang secara ilegal menuju Arab Saudi untuk mencari pekerjaan. Pada tahun 2013, pemerintah Arab Saudi menuntut agar sekitar 1,5 juta pekerja ilegal asal Yaman melaporkan diri atau segera meninggalkan Arab Saudi. Pada tahun 2014, sekitar 800.000 pekerja ilegal terancam dideportasi. Arab Saudi tentu tidak ingin membiarkan terus masuknya pekerja ilegal asal Yaman ke negaranya karena dengan bertambahnya jumlah pekerja ilegal asal Yaman akan berdampak kepada jumlah pengangguran dan meningkatnya anggaran belanja pemerintah Arab Saudi. Selain itu, daerah perbatasan menjadi daerah operasi sindikat penyelundup obat bius dan perdagangan manusia. (Dw.com, 2017).

Daerah perbatasan antara Arab Saudi dan Yaman juga menjadi basis dari kelompok Houthi yang merupakan kelompok pemberontak di Yaman. Basis kelompok Houthi berada di provinsi Sa'adah di daerah Yaman bagian utara. Perlawanan kelompok Houthi dianggap membahayakan keamanan nasional Arab Saudi karena pergerakan kelompok Houthi mampu mencapai wilayah teritorial Arab Saudi. Pergerakan kelompok Houthi diawali dengan melintasi perbatasan Arab Saudi yang mengakibatkan tewasnya penjaga perbatasan Arab Saudi dan menduduki Jabal Dukhan yang notabene merupakan wilayah Arab Saudi di perbatasan Arab Saudi-Yaman. Pada tanggal 5 Mei 2015, milisi Houthi melancarkan aksi dengan menyerang perbatasan Arab Saudi-Yaman dan menewaskan dua warga sipil Arab Saudi dan menyandera lima tentara perbatasan. Pada tanggal 1 Juni 2015, kelompok Houthi kembali menyerang perbatasan kedua negara yang dilancarkan dari seberang Yaman dengan menghujani tembakan ketika tentara Arab Saudi sedang melakukan patroli keamanan di kota Harth, daerah Jazan, bagian selatan perbatasan Arab Saudi-Yaman. 
Serangan kelompok Houthi semakin mengkhawatirkan Arab Saudi setelah adanya peningkatan jumlah serangan rudal balistik dan pesawat tanpa awak yang menargetkan kota-kota di wilayah utara Arab Saudi, termasuk Riyadh. Pada bulan Juli 2015, pasukan kelompok Houthi menembaki kamp militer Arab Saudi yang berada di provinsi Jizan. Dalam rentang waktu bulan Mei 2015 hingga 27 Januari 2017, Kerajaan Arab Saudi telah mencegat lebih dari 40 rudal yang diluncurkan dari Yaman menuju wilayah Arab Saudi (CSIS, 2016). ${ }^{1}$ Berikut pernyataan dari Menteri Luar Negeri Adel al-Jubeir terkait serangan rudal kelompok Houthi ke wilayah Arab Saudi:

"...There was no way that we were going to allow a radical militia allied with Iran and Hezbollah (Houthi), in possession of ballistic missiles and an air force, to take over a country that is strategically important to the world and that is our neighbor."

"Iranian interventions in the region are detrimental to the security of neighboring countries and affect international peace and security. We will not allow any infringement of our national security." (arabnews.com, 2018)

Berdasarkan kedua pernyataan di atas, dapat disimpulkan bahwa kepentingan utama Arab Saudi dalam intervensi militernya ke wilayah Yaman adalah untuk menjaga stabilitas keamanan nasional negaranya dan melindungi wilayah perbatasan antara Arab Saudi Yaman agar tercipta rasa aman bagi warga sipil Arab Saudi yang tinggal di wilayah perbatasan.

\section{Persepsi Arab Saudi terhadap Ancaman Iran}

Tindakan intervensi militer Arab Saudi terhadap Konflik Yaman juga disebabkan adanya persepsi ancaman yang timbul oleh Arab Saudi terhadap Iran. Persepsi berisikan seperangkat informasi yang membentuk image Iran dalam pandangan Arab Saudi. Persepsi Arab Saudi terhadap ancaman Iran terbentuk oleh beberapa faktor, seperti peran ulama dan pengaruh nilai dan norma Sunni - Syi'ah, aktor eksternal dalam dinamika hubungan Arab Saudi - Iran, serta peran media massa.

\section{Peran Ulama dan Pengaruh Nilai dan Norma Sunni - Syi’ah}

Arab Saudi dikenal sebagai penganut paham Wahabi yang pertama kali diperkenalkan oleh syeikh Muhammad bin Abdul Wahhab pada tahun 1740. Paham Wahabi mendasarkan pemahaman syariat (hukum) Islam hanya bersumber dari Al-Qur'an dan Sunnah tanpa memberikan ruang penafsiran terhadap kedua sumber hukum tersebut (Schanzer, Miller. 2012). Konkritnya, Wahabisme menolak pemahaman kelompok Islam

\footnotetext{
${ }^{1}$ The Missile War in Yemen; Missile Defense Project, Center for Strategic and International Studies.2016
} 
lain yang tidak sesuai dengan pandangan mereka, khususnya kelompok Syi'ah. Meskipun secara fundamental paham Wahabi berbeda dengan penganut Islam Sunni, namun Arab Saudi mewakili blok negara-negara Sunni yang merupakan sekutu Arab Saudi di Timur Tengah.

Pemerintahan Arab Saudi merupakan perpaduan antara kekuasan politik dan semangat keagamaan. Penguasa Arab Saudi menggunakan Al-Qur'an dan Hadist sebagai landasan ideologi untuk melindungi kekuasaan. Dengan kekuasaan raja Arab Saudi yang sangat luas, menjadikan Raja sebagai Imam dari para ulama. Dengan demikian, yang menjadi dasar pertimbangan Arab Saudi dalam intervensi militer terhadap konflik Yaman adalah adanya faktor dorongan para ulama Arab Saudi kepada pemerintah yang menyerukan untuk melawan agresor Syi'ah demi stabilitas keamanan Arab Saudi. Sebanyak 46 ulama menyatakan dukungannya termasuk di dalamnya Sheikh Nasser bin Suleiman Omr yang merupakan pengawas umum situs The Muslim dan Sheikh Suleiman bin Hamad Awda yang merupakan anggota fakultas di Universitas Qassim yang juga berperan sebagai imam dan khatib. Sejumlah khatib sholat Jumat di Arab Saudi juga memberikan dukungan untuk melawan agresor Syi'ah dengan mengecam tindakan kelompok pemberontak Houthi. Para khatib tersebut menganggap intervensi militer yang dilakukan Arab Saudi ke Yaman merupakan jihad melawan kelompok pemberontak seperti al-Houthi.

Pada 2 Januari 2016, Arab Saudi mengumumkan eksekusi ulama Syi'ah Sheikh Nimr al Nimr yang telah menyuarakan perlawanan terhadap keluarga Kerajaan Arab Saudi (Mamadkul, 2016). Arab Saudi menjatuhkan vonis hukuman mati terhadap al Nimr pada tahun 2011 setelah didakwa membangkang terhadap perintah negara dan dituduh merencanakan pembunuhan terhadap aparat keamanan. Nimr merupakan ulama Syi'ah Arab Saudi yang konsisten menentang praktik diskriminasi terhadap kaum Syi'ah di Arab Saudi (DW, 2018). Nimr ditangkap pada tahun 2012 setelah menyerukan provinsi Qatif dan Al - Ihsaa untuk memisahkan diri dari Arab Saudi dan bergabung dengan Bahrain. Sejak 2015, Arab Saudi telah melakukan lebih dari 150 eksekusi terhadap komunitas Syi'ah yang merupakan angka tertinggi yang pernah tercatat oleh kelompok hak asasi manusia selama 20 tahun (BBC, 2018).

Menurut Sheikh Abdul Aziz al-Sheikh yang merupakan tokoh ulama popular Wahabi di Arab Saudi menyatakan bahwa: "We must understand these are not Muslims. They are the son of the Magi and their hostility towards Muslims is an old one, especially 
with the People of the Tradition (Sunnis)." (Independent, 2018)

Persepsi para ulama Arab Saudi mengklaim bahwa Syi'ah sebagai ajaran menyimpang dalam Islam atau bahkan sudah keluar dari Islam. Persepsi ini kemudian menjadikan komunitas Syi'ah yang berada di Arab Saudi sebagai warga negara kelas dua dan dibatasi segala aktifitas keagamaannya. Seperti, pengawasan ketat pemerintah terhadap paraktek-praktek ibadah komunitas Syi'ah, pelarangan penyebaran azan secara publik, pelarangan penyebaran teks-teks keagamaan dan politik secara publik, pembatasan pembangunan masjid, serta pembongkaran pusat-pusat pendidikan agama dan tempattempat yang dianggap suci oleh komunitas Syi'ah (International Crisis Group, 2018).

Populasi komunitas Syi'ah di Arab Saudi berjumlah sekitar 15\% dari total 25 juta penduduk Arab Saudi. Komunitas Syi'ah di Arab Saudi berbasis di kota-kota seperti Qatif, Dammam, al-Hasa dan sepanjang pantai Teluk Parsi. Hal ini membuat keberadaan komunitas Syi'ah menjadi perhatian bagi pemerintah Arab Saudi karena basis wilayah yang dihuni komunitas ini merupakan lokasi yang kaya akan sumber daya minyak. Ladingladang minyak terbesar di dunia seperti Ghawar dan Qatif berada di provinsi Hasa. Walaupun komunitas Syi'ah Arab Saudi sebagian besar tinggal di daerah yang kaya akan minyak, namun dalam kenyataannya mereka sering mendapat perlakuan diskriminatif oleh rezim pemerintahan Arab Saudi. Pemerintah juga kurang memperhatikan kebutuhan sosial komunitas Syi'ah di Arab Saudi. Kota-kota yang didiami komunitas Syi'ah seperti Hufuf dan Qatif jauh lebih terbelakang jika dibandingkan dengan kota-kota yang berpenduduk Islam Wahabi (refworld, 2005). Meskipun tergolong kaum minoritas, Arab Saudi menganggap keberadaan komunitas Syi'ah ini dapat menjadi ancaman bagi Kerajaan apabila terpengaruh oleh kebangkitan kelompok Houthi yang juga berbasis Islam Syi' ah di Yaman. Arab Saudi juga meyakini adanya hubungan antara keberadaan komunitas Syi'ah ini dengan pemerintah Iran sebagai satu-satunya pemerintahan yang bermazhab Syi'ah di dunia.

\section{Aktor Eksternal dalam Dinamika Hubungan Arab Saudi - Iran}

Hubungan Arab Saudi - Iran sering mengalami pasang surut dimana hubungan kedua negara cenderung mengarah ke persaingan dalam berbagai aspek baik dalam aspek ideologi, agama, maupun politik terutama sejak Iran mengalami revolusi. Revolusi Islam Iran yang terjadi pada awal Februari 1979 merupakan sebuah peristiwa yang menjadi titik awal mula persaingan dalam perang dingin di Timur Tengah. Ayatollah Khomeini yang 
menjadi pemimpin Revolusi Islam Iran memunculkan konsep pemerintahan baru yang menjadikan kaidah agama Islam sebagai landasan fundamental. Konsep pemerintahan tersebut menggantikan pemerintahan dinasti Shah Pahlevi yang sebelumnya menggunakan model kerajaan dengan pemerintahan yang sekuler dan pro-barat. Konsep pemerintahan baru tersebut merupakan gagasan langsung dari Khomeini yang dikenal sebagai "Wilayah Al-Faqih". Konsep ini memformulasikan antara nilai demokrasi dengan kaidah agama Islam dengan meniscayakan kepemimpinan seorang fakih (ahli syari'at agama Islam) dalam sebuah pemerintahan (Annis, 2015).

Berubahnya haluan politik Iran menjadi anti-Amerika beserta negara sekutunya di Timur Tengah termasuk Israel dan Arab Saudi juga mengubah tatanan geopolitik di kawasan. Revolusi Iran lebih spesifik dipandang sebagai pemantik permusuhan antara Arab Saudi dan Iran yang menyebabkan hubungan diplomatik kedua negara yang sebelumnya cenderung stabil dan harmonis menjadi bernuansa persaingan di berbagai lini dan memanas dalam koridor rivalitas geopolitik di kawasan Timur Tengah.

Pada dasarnya revolusi Islam Iran merupakan ancaman bagi Arab Saudi dan negaranegara Arab pada umumnya yang menerapkan sistem pemerintahan monarki. Secara politis, kedua negara memiliki sistem pemerintahan yang saling bersinggungan. Pada satu sisi, Iran sebagai representasi blok revolusioner menentang imperialism, disisi lain Arab Saudi dan negara-negara Teluk sebagai representasi negara monarki yang mencoba untuk mempertahankan status quo mereka. Terlebih pada pertengahan 1979 ketika Khomeini mulai menegaskan peran Iran untuk memperluas pengaruhnya dengan cara "ekspor revolusi" di negara-negara Iran (Karsh, 2002). Arab Saudi melihat maneuver ekspor revolusi yang bermuara di Teheran tersebut sebagai ancaman bagi status quo kerjaan mereka.

Para pemimpin Kerajaan Arab Saudi mengemas persaingannya dengan Iran dengan istilah sektarian dan menuduh bahwa Iran telah memicu konflik sektarianisme dengan mendukung milisi Syi'ah yang menargetkan negara yang mayoritas penduduknya merupakan Sunni seperti Irak, Lebanon, Suriah, dan Yaman (Dorsey, 2016). Jatuhnya rezim Shah Iran yang otokratik memberikan tempat bagi sebuah rezim baru yang revolusioner. Pasca revolusi, Iran menjadi sebuah negara republik yang anti terhadap sistem pemerintahan monarki absolut seperti yang dijalankan Arab Saudi dan mencoba untuk mengekspor nilai-nilai revolusinya ke negara-negara Teluk. Hal tersebut kemudian dianggap menjadi sebuah ancaman bagi stabilitas kerajaan Arab Saudi. 
Selain peran ulama dan pengaruh nilai dan norma dalam negeri Arab Saudi, adanya faktor eksternal juga mempengaruhi persepsi Arab Saudi terhadap ancaman Iran. Faktor eksternal tersebut adalah aliansi yang dibangun oleh Arab Saudi dengan Amerika Serikat. Aliansi Arab Saudi - Amerika Serikat berlangsung sejak Perang Dunia II ketika kedua negara bersekutu untuk melawan komunisme, mendukung harga minyak yang stabil, stabilitas produksi dan distribusi minyak, dan stabilitas ekonomi negara-negara Barat. Khususnya kedua negara bersekutu untuk melawan Uni Soviet di Afghanistan dan mengusir Irak keluar dari Kuwait pada tahun 1991 (Grayson, 1982). Hingga saat ini, sikap anti-Amerika beserta negara-negara sekutunya yang dianut Iran dianggap sebagai ancaman oleh Amerika Serikat dan Arab Saudi dalam mencapai kepentingan masing-masing negara.

Setelah melakukan revolusi pada tahun 1979, orang-orang Iran terus meneriakkan "Death to America" dan "Great Satan" sebagai bentuk pernyataan sikapnya yang antiAmerika (Hart, 2002). Pada tahun 2002, Presiden George W. Bush dalam pidatonya mendefenisikan Iran sebagai poros kejahatan. Bush menyatakan bahwa: "States like these, and their terrorist allies, constitute an axis of evil, arming to threaten the peace of the world."(Whitehouse.gov, 2001).

Pada tahun 2008, Raja Abdullah bersama Adel al-Jubeir yang pada saat itu menjabat sebagai Duta Besar Arab Saudi untuk Amerika Serikat, mengadakan pertemuan dengan Jenderal David Patraeus yang merupakan komandan militer tertinggi Amerika Serikat di Timur Tengah. Al-Jubeir mengatakan bahwa: "He (King Abdullah) told you to cut off the head of the snake,' adding that working with the US to roll back Iranian influence in Iraq is a strategic priority for the King and his government” (Whitehouse.gov, 2001).

Selain itu, dalam wawancaranya dengan Hadley Gambley dari CNBC, Menteri Luar Negeri Adel al-Jubeir juga mengatakan bahwa:

HG: In terms of the dangerous nations behind those cyber attacks, Russia, China, North Korea, Iran. Who do you consider the most dangerous nation?

FM: Iran. Iran is the only country that has attacked us repeatedly and has tried to attack us repeatedly. In fact, they tried to do it on a weekly basis (CNBC, 2018).

Berdasarkan pernyataan di atas, dapat disimpulkan bahwa persepsi Arab Saudi terhadap Iran adalah ancaman nyata yang dapat mengganggu stabilitas dan kepentingan negaranya. Hal ini terlihat dari kata “...cut off the head of snake...” yang digunakan oleh Raja Abdullah sebagai sebuah analogi yang menggambarkan ancaman Iran. Sedangkan pada pernyataan kedua, Menteri Luar Negeri Adel al-Jubeir secara terang-terangan 
mengatakan bahwa Iran adalah negara paling berbahaya dan telah menyerang wilayah mereka berulang kali. Selain itu, persepsi Arab Saudi terhadap ancaman Iran juga berkembang karena dipengaruhi oleh aliansi yang dibangun Arab Saudi dengan Amerika Serikat.

\section{Pengaruh Media}

Selain faktor peran ulama dan nilai-nilai Sunni - Syi'ah serta faktor kedekatan antara Arab Saudi dengan Amerika Serikat, media juga memberikan pengaruh terhadap pembentukan persepsi Arab Saudi terhadap ancaman Iran. Media massa cenderung mengkemas alasan ideologis dan sektarian dalam menggambarkan ketegangan kawasan Timur Tengah. Media merupakan acuan wacana politik di Arab Saudi, dengan data dan informasi yang diterbitkan media setiap harinya menjadikan faktor pemerintah untuk lebih intens mengatasi ancaman Iran dan pemberontakan kelompok Houthi yang mengancam stabilitas keamanan dalam negerinya. Oleh karena itu, media yang berbasis pada Arab Saudi seperti Al Jazeera ikut serta berkontribusi dalam memberikan informasi yang tidak hanya di level nasional tetapi juga internasional, termasuk berkaitan dengan konflik Yaman.

Saudi Arabia has assembled a "massive" additional force on its border with Yemen after trading heavy artillery and rocket fire with Yemen's Houthi fighters, prior to a proposed truce taking effect.

Al Jazeera's Mohamed Vall, reporting from Riyadh, said Saudi Arabia's defence ministry announced on Monday that a "massive" force had reached Najran on its way to taking its position on the frontlines adjacent to Yemeni territory, following Monday's exchange of fire.

He said the ministry did not specify the size of the force assembled but stated that it included advanced armaments capable of fighting in rugged mountainous areas. Footage showing rows of tanks and armoured personnel carriers loaded on military vehicles headed towards Yemen were aired on a Saudi-owned television channel.

The Houthis said they fired Katyusha rockets and mortars on the Saudi cities of Jizan and Najran earlier on Monday, after Saudi forces hit Saada and Hajjah provinces with more than 150 rockets. Saudi Arabia's civil defence department said one Saudi national was killed in the shelling in Najran, which it said targeted a school and residence adjacent to a military post.

Another Saudi citizen and three expatriates were also injured in the fire, the department said. Also, fighter jets from the Arab coalition struck positions of the Houthis, believed to be backed by Iran, in the central city of Taiz and in the oil-producing Marib province east of the capital, Sanaa........(Al Jazeera, 2015)

Berita internasional tersebut mempublikasikan konflik yang terjadi di di perbatasan Arab Saudi - Yaman memunculkan sebuah fakta dalam berita yang disajikan. Ada sebuah formula atau strategi dalam mengemas peristiwa dalam bentuk berita. Berita ini 
menunjukkan adanya fakta bahwa roket yang ditembakkan oleh kelompok Houthi berhasil mencapai wilayah Jizan dan Najran serta Arab Saudi percaya bahwa kelompok Houthi didukung oleh Iran.

In the Gulf, there will be a continuous demand for such arms deals driven by perceptions of a growing "Iranian threat"; this sits well with anti-Iran hawks in Washington.

Iran has exploited much of the chaos in post-2003 Iraq, the Syrian civil war, sectarian unrest in Bahrain, the Yemeni Arab Spring of 2011 and the collapse of the government in Sanaa in 2014. Arab governments and societies that fail to effectively deal with issues of poverty, youth unemployment, ethnic and sectarian marginalisation, human rights abuses, and high levels of social inequality will remain vulnerable to Iran's efforts to capitalise on Arab states' internal weaknesses.

Put simply, to push back against Iranian influence, Arab governments must improve their standing with certain segments of their societies that see no sound alternative but to look to foreign powers such as Iran for support. Arms purchases worth billions of dollars will not solve the domestic problems of Arab countries.

Ultimately, arms sales serve a political purpose at a time of increasingly confrontational rhetoric between the US, GCC states, and Iran. Officials in Tehran, however, see through the arms charade and are aware of the show Trump is putting up for his domestic audience.

So Gulf states will need a much more comprehensive approach towards Iran than spending billions on US arms to curb its growing influence and shield themselves from regional instability and violent extremists. (Al Jazeera, 2018).

Dari pemberitaan tersebut ditunjukkan bahwa Arab Saudi memandang Iran sebagai penyebab dari kekacauan yang terjadi di Timur Tengah sejak invasi di Irak pada tahun 2003, konflik Suriah, pergerakan sektarian di Bahrain, dan runtuhnya pemerintahan Yaman pada tahun 2014. Pemberitaan-pemberitaan yang dikeluarkan oleh media seperti ini dapat membentuk opini publik dalam memahami persepsi Arab Saudi terhadap ancaman Iran.

Dari penjelasan di atas, dapat disimpulkan bahwa peran ulama serta nilai-nilai dan norma Sunni - Syi'ah beserta Amerika sebagai aktor eksternal mengarahkaan Arab Saudi untuk melihat ancaman Iran sebagai disorted perception. Selain itu, persepsi Arab Saudi yang melihat Iran sebagai ancaman juga diarahkan oleh media dan dapat diklasifikasikan sebagai diffused perception. Sedangkan untuk membuktikan persepsi Arab Saudi based on reality yang melihat Iran sebagai ancaman belum peneliti temukan karena keterbatasan data dan informasi.

\section{KESIMPULAN}

Arab Saudi memiliki ambisi untuk menjadi pemimpin di dunia Arab dan Islam yang diusahakan melalui penjagaan terhadap stabilitas dalam negeri dan pengaruh hegemoninya di kawasan Timur Tengah. Kawasan Timur Tengah merupakan 
kawasan yang strategis di dunia karena berada di antara benua Asia, Afrika dan Eropa. Kawasan Timur Tengah juga kaya akan sumber daya alam berupa minyak bumi serta berada diantara jalur perdagangan minyak dunia. Dalam menjaga stabilitas dan pengaruhnya di Timur Tengah, Arab Saudi harus berhadapan dengan Iran yang merupakan kekuatan regional lainnya dan bertentangan dengan sistem politik Arab Saudi. Sejak melakukan revolusi, Iran mencoba untuk memperluas pengaruhnya di Timur Tengah dengan mengekspor gagasan revolusi Syi'ahnya dan melakukan manuver-manuver yang signifikan dalam menanggapi konflik yang terjadi di kawasan. Kebijakan yang diberlakukan oleh Iran kemudian menjadi sebuah ancaman bagi Arab Saudi dalam mencapai tujuan dan kepentingan-kepentingannya. Tindakan intervensi militer Arab Saudi terhadap konflik Yaman disebabkan oleh beberapa motif.). Dari pengolahan data serta analisis dari ketiga indikator tersebut didapatkan hasil bahwa motif intevensi militer Arab Saudi terhadap konflik Yaman adalah perebutan power di Timur Tengah melalui penguasaan jalur perdagangan minyak, kepentingan keamanan nasional Arab Saudi, dan persepsi Arab Saudi terhadap ancaman Iran yang tergolong distorted dan diffuse perception.

\section{DAFTAR PUSTAKA}

Al Jazeera, Saudi Arabia Assembles 'Massive Force' on Yemen Border, https://www.aljazeera.com/news/2015/05/cloneof150511081959228150511134843562.html, diakses pada 12 September 2018.

Al Jazeera, The GCC's Arms Race and the Iranian 'threat', https://www.aljazeera.com/indepth/opinion/gcc-arms-race-iranian-threat171228130337650.html, diakses pada 9 Oktober 2018.

Anthony H. Cordesman, America, Saudi Arabia, and the Strategic Importance of Yemen, Center for Strategic \& International Studies.

Arabnews.com, Missile attack on Riyadh 'an act of war' by Iran, http://www.arabnews.com/node/1189476/saudi-arabia, diakses pada 2 Oktober 2018.

Bbc.com, How Yemen's capital Sanaa was seized by Houthi rebels, http://www.bbc.com/news/world-29380668, diakses pada 20 Februari 2018.

BBC, Sheikh Nimr al-Nimr: Saudi Arabia executes top Shia cleric https://www.bbc.com/news/world-middle-east-35213244, diakses pada 9 Oktober 2018.

Bernard Haykel, "Act locally: why the GCC needs to help save Yemen", The National (UAE), January 7th, 2010.

Blair, Dennis C. "Annual Threat Assessment of the US Intelligence Community for 
the Senate Select Committee on Intelligence”, February 2, 2010.

Charles Schmitz, Yemen's Importance to Saudi Arabia, https://www.thecipherbrief.com/yemens-importance-to-saudi-arabia, diakses pada 20 Juli 2018.CNBC, Interview with Saudi Foreign Minister, Adel Al-Jubeir, 19 Feb 2018, https://www.cnbc.com/2018/02/19/cnbcinterview-with-saudi-foreign-minister-adel-al-jubeir.html, diakses pada 4 Oktober 2018.

CNN, "Saudi Arabia launches airstrakes in Yemen", ( March 26th, 2015). https://edition.cnn.com/2015/03/25/middleeast/yemen-unrest/, diakses pada 21 Februari 2018.

Country Profile: Yemen, Library of Congress - Federal Research Division, August 2008.

DW.com, Arab Saudi Perketat Penjagaan Perbatasan, https://www.dw.com/id/arabsaudi-perketat-penjagaanperbatasan/a-17410217, diakses pada 8 September 2018.

DW, Siapa Nimr al Nimr, yang Menyulut Konflik Iran dan Arab Saudi?, https://www.dw.com/id/siapa-nimr-al-nimr-yang-menyulut-konflik-irandan-arab-saudi/a-18958741, diakses pada 30 September 2018.

Efraim Karsh, Essential Histories the Iran-Iraq War 1980-1988, Osprey Publishing, 2002.

Financial Times, Digby Lidstone, "Yemen Hopes Gas Will Fuel Recovery", May 4, 2009; "Yemen Seeks Changes to Oil-Production Sharing Agreements", Saba News Agency (Sana'a), December 28, 2009; Ulf Laessing, "Yemen's Central Bank Forecasts up to 8 Percent Growth in 2010", Reuters, January 26, 2010

Fozia Jan and Shazia Majid. "Yemen Crisis and the Role of Saudi Arabia". International Journal of Arts and Humanities. (January 2017).

George W. Bush, State of the Union Address, Washington, D.C., 29 January 2001, www.whitehouse.gov/news/releases/2002/2002012911.html, diakses pada 9 Oktober 2018.

Grayson, Benson Lee. Saudi-American relations. University Press of America. 1982.

Guardian, US Embassy Cables: Saudi King Urges US Strike on Iran, November 28th 2010, https://www.theguardian.com/world/us-embassy-cablesdocuments/150519, diakses pada 7 Oktober 2018.

Independent, 'Iranians are not Muslims', says Saudi Arabia's Grand Mufti, https://www.independent.co.uk/news/world/middle-east/saudi-arabia-grandmufti-iran-sunni-muslims-hajj-a 7229416.html, diakses pada 7 Oktober 2018.

International Crisis Group, The Shiite Question in Saudi Arabia, Crisis Group Middle East Report No. 45, hal: 2, https://www.files.ethz.ch/isn/13612/045_shiite_question_saudi\%20arabia.p df, diakses pada 7 Oktober 2018.

James M. Dorsey, Saudi Arabia and Iran: The Battle for Hegemony that the Kingdom 
Cannot Win, S. Rajaratnam School of International Relations, Singapore. 2016.

Jeremy M. Sharp, "Yemen: Background and U.S. Relations", Congressional Research Service, March 3rd, 2011.

Jirajoj Mamadkul, “Saudi Arabia - Iran's Foreign Policy Crisis: A Case Study of Execution of Saudi Shia Cleric Shaikh Nimr al-Nimr", (Institute of Diplomacy and International Study, Rangsit University, 1 November 2016).

Jo-Anne Hart, Perceptions and Courses of Actions toward Iran, https://www.armyupress.army.mil/Portals/7/Hot\%20Spots/Documents/SAIran/Hart-Iran-2005.pdf, diakses pada 9 Oktober 2018.

Marc Moussalli, Not Just a Proxy War: Yemen's Strategic Importance, https://globalriskinsights.com/2015/04/not-just-a-proxy-war-yemensstrategic-importance/, diakses pada 20 Juli 2018.

Martina Fuchs, "Gas Probably Not Enough to Buoy Yemen," Reuters, August 24, 2009.

Michael Makovsky, Blaise Misztal, dan Jonathan Ruhe, Fragility and Extremism in Yemen, A Case Study of The Stabilizing Fragile States Project, Bipartisan Policy Center, Januari 2011.

Michael Makovsky, Blaise Misztal, and Jonathan Ruhe. Fragility and Extremism in Yemen, Bipartisan Policy Center, January 2011.

Muhammad Annis, Pemikiran Politik Syi'ah: Perspektif Wilayah Al-Faqih. Maarif Institute, 2015

Muqtedar Khan, "Saudi Arabia's Foray into Military Intervention", https://www.huffingtonpost.com/muqtedar-khan/saudi-arabias-foray-into_b_836842.html, diakses pada 28 Februari 2018.

Peter Alsis, Marissa Allison, and Anthony H. Cordesman, US and Iranian Strategic Competition in the Gulf States and Yemen, Center for Strategic \& International Studies, 2011.

R. Grumet, Tali. New Middle East Cold War: Saudi Arabia and Iran's Rivalry, University of Denver, 2015

Robert C. Bogdan and Sari Knopp Biklen, "Qualitative Research For Education: An Introduction to Theories and Methods". (Second Edition: 1992)

Saudi Arabia, https://www.opec.org/opec_web/en/about_us/169.htm, diakses pada 20 Juli 2018.

Saudi Arabia: Political, Economic and Social Development Report, 2017, https://www.saudiembassy.net/sites/default/files/WhitePaper_Development _May2017.pdf, diakses pada 8 September 2018.

Sigit Priambodo, Motif Intervensi Arab Saudi Terhadap Perang Saudara di Yaman, Departemen Hubungan Internasional, Fakultas Ilmu Sosial dan Ilmu Politik, Universitas Airlangga, 2017.

Steven Schanzer, Jonathan and Miller, Facebook Fatwa: Saudi Clerics, Wahhabi Islam and Social Media, Washington DC: Foundation for Defense of Democracies Press 
The Guardian, "Saudi Arabian intervention in Bahrain driven by visceral Sunni fear of Shias", https://www.theguardian.com/world/2011/mar/20/bahrain-saudiarabia-rebellion, diakses pada 28 Februari 2018.

The Missile War in Yemen; Missile Defense Project, Center for Strategic and International Studies.

The New York Times, "Saudi Arabia Leads Air Assault in Yemen", (March 25th, 2015). https://www.nytimes.com/2015/03/26/world/middleeast/al-anad-airbase-houthis-yemen.html, diakses pada 21 Februari 2018.

The Shiite Question in Saudi Arabia, International Crisis Group, 2005, http://www.refworld.org/pdfid/43bd1ce24.pdf, diakses pada 12 September 2018

Usjid U. Hameed, "The Saudi-Iranian Rivalry: A Foreign Policy Analysis Approach", (Towson University Journal of International Affairs).

Vickie A. Lambert, Clinton E. Lambert, Qualitative Descriptive Research: An Acceptable Design, 2.

Voice of Palestine, Minyak dan Geopolitics Bercampur. http://voiceofpalestine.net/perang-di-yaman-minyak-dan-geopolitikbercampur/, diakses pada 20 Juli 2018.

Wawancara Isobel Coleman - Menteri Luar Negeri Arab Saudi, Adel al-Jubeir, Council on Foreign Relations.

Yemen 2105 International Religious Freedom Report, https://www.state.gov/documents/organization/256509.pdf

Yemen Population, http://www.worldometers.info/world-population/yemenpopulation/, diakses pada 24 Juli 2018.

Zada, Khamami. Gelombang Revolusi dan Tansisi Politik di Timur Tengah dan Afrika Utara. Fakultas Syariah dan Hukum UIN Syarif Hidayatullah Jakarta. 2016 